\title{
MARKET PRODUCTION OF MEAT AS A FACTOR OF THE ACHIEVED LEVEL OF DEVELOPMENT OF SERBIAN AGRICULTURE
}

\author{
Simo Stevanović1, Goranka Kneževićn ${ }^{2}$ Nenad Kojić ${ }^{3}$ \\ *Corresponding author E-mail: simo.stevanovic@agrif.bg.ac.rs
}

\begin{abstract}
A R T I C LE I N F O
Original Article

Received: 10 July 2018

Accepted: 21 November 2018

doi:10.5937/ekoPolj1804411S

UDC 338.439.4:637.5(497.11)

Keywords:

market production of meat, achieved level of economic development, I-distance, cluster analysis.
\end{abstract}

JEL: Q13, 011

\begin{abstract}
A B S T R A C T
In the paper, the mutuality of the market production of beef, pigmeat, sheep meat and poultry meat and the achieved level of development of agriculture as per Serbia's districts in the period from 2001 to 2016 are analyzed. The ranking of districts in Serbia is done by the I-distance method. Similarities are determined by cluster analysis method, while results are represented by a dendrogram. Belgrade District shows a deficit in the market production of all meats. In the three districts of Vojvodina Region, there is a deficit in sheep meat and in the two districts, there is a deficit in poultry meat. The three districts of Sumadija and Western Serbia Region, there is a deficit in the production of pigmeat and poultry meat. The Region of Southern and Eastern Serbia has a deficit in the production of poultry meat.
\end{abstract}

(C) 2018 EA. All rights reserved.

\section{Introduction}

In the development of Serbia's economy, agriculture has provided accumulation and workforce for the development of non-agricultural activities, raw materials for the processing industries, a major user of the outputs of industrial products, and the significant harmonization of the country's foreign-trade balance. Activities in agriculture have an influence on the protection and improvement of the living environment and the concept of sustainable development. For that reason today, agriculture is said to be playing a multifunctional role in economic development.

The growth of the living standard and quality of nutrition of a population has an influence on increased demand for livestock products. The interdependence of

1 Simo Stevanović, Ph.D., Full Professor, University of Belgrade, Faculty of Agriculture, Nemanjina 6, 11080 Belgrade, Republic of Serbia, phone: +381114413418 , e-mail: simo. stevanovic@agrif.bg.ac.rs, ORCID ID (https://orcid.org/0000-0002-9188-5929).

2 Goranka Knežević, PhD in Accounting, Singidunum University, Faculty of Business, Belgrade, Serbia, e-mail: gknezevic@singidunum.ac.rs. ORCID ID (https://orcid.org/00000003-3642-7682).

3 Nenad Kojić, PhD., University of Pristina, Faculty of Economics, Kosovska Mitrovica, Serbia, e-mail: nenead.kojic@pr.ac.rs, ORCID ID (https://orcid.org/0000-0001-5399-8132). 
economic development, personal income and livestock production is important for defining the developmental policy of agriculture, and livestock production within it. Apart from their positive effects, global business and economic development during the last decades have also resulted in numerous negative effects that have become apparent in the field of human nutrition and health. Various forms of pollution, as well as inappropriate nutrition, have initiated new trends in nutrition, such as organic, macrobiotic, functional, etc. Some are the consequence of the global economic strategy or the limits of the existing resources, and as often as not, they are the consequence of economic and political interests (Stevanović, 2005).

The development of agriculture in Serbia primarily depends on soil and natural conditions. This is indicative of the need for territorialization in order to achieve better results in agriculture, especially in plant and livestock production, which are directly dependent upon natural conditions. Using comparative natural advantages contributes to the uniform territorial development of Serbia.

As a significant economic branch in every country, agriculture has its locomotive of development, which namely is animal husbandry. Animal husbandry also has its main artery represented by milk production. The previously established fact enables us to conclude that agriculture and animal husbandry are interwoven, that animal husbandry leans against agriculture and represents a higher stage of agricultural products (Tomić, D., Simonović, V., 2008).

For the reason of the specificity of production and developmental features, the paper starts from the hypothesis that in Serbia, the regionalization of the production of meat (beef, pigmeat, sheep meat and poultry meat) is pronounced. Even though livestock production depends on natural conditions to a lesser degree than crop production, the distinct regionality of the production of each one of the analyzed meats can be spoken about. The presence of these types of production and an increase in marketability are assumed to have a positive influence on total agricultural, i.e. the achieved level of economic development of the districts in Serbia.

The goal of the paper is to analyze the development of the market production of meat as per districts in Serbia on the basis of the three groups of features: production, capacities and the achieved level of development. On the basis of these features, the I-distance was used to rank the districts in Serbia.

The results of the research study of the features of the capacities, production and development represent a good basis for implementing production regionalization and pursuing an agrarian policy towards the districts that belong to the same cluster.

\section{Method of Work and Data Sources}

By analyzing the production of meat as per districts in Serbia, it has been determined that there is a connection between the volume of meat production, the available capacities and the achieved development level.

4 Ivanović's Distance. 
During the analysis of the market production of meat, the territorial organization of Serbia was taken into account. The Serbian territory is presented according to the Regulation on the Nomenclature of the Statistical Territorial Units. With respect to its territorial organization, Serbia applies the EU standards in the domain of statistical organizing (NUTS and LAU levels). The NUTS-1 Level of Serbia encompasses two regions (Serbia-North and Serbia-South). The NUTS-2 Level of Serbia encompasses five regions (Vojvodina Region, Belgrade Region, Šumadija and Western Serbia Region, Southern and Eastern Serbia Region and the Region of Kosovo and Metohija). The NUTS-3 Level encompasses 25 districts, and the NUTS-4 Level encompasses municipalities in Serbia (Devetaković, 2008).

The ranking of the districts by the I-distance method was done on the basis of the three groups of features: a) production $\left(8\right.$, from $\mathrm{x}_{1}$ to $\left.\mathrm{x}_{8}\right)$ : $\mathrm{x} 1$-beef production as per districts, $\mathrm{x} 2$-pigmeat production as per districts, $\mathrm{x}_{3}$-sheep meat production as per districts, $\mathrm{x}_{4}{ }^{-}$ poultry meat production as per districts, $\mathrm{x}_{5}$-the marketability degree of beef as per districts, $\mathrm{x}_{6}$-the marketability degree of pigmeat as per districts, $\mathrm{x}_{7}$-the marketability degree of sheep meat as per districts, $\mathrm{x}_{8}$-the marketability degree of poultry meat as per districts; $\mathrm{b}$ ) the capacities $\left(7\right.$, from $x_{9}$ to $\left.x_{15}\right): x_{9}$-the number of bovines as per districts, $x_{10}$-the number of pigs as per districts, $x_{11}$-the number of sheep as per districts, $x_{12}$-the number of poultry as per districts, $\mathrm{x}_{13}$-the number of bovines on 100 ha of arable area, $\mathrm{x}_{14}$-the number of pigs on 100 ha of a ploughland area, $x_{15}$-the number of sheep on 100 ha of an agricultural area, and $\mathrm{c}$ ) the level of achieved development (5, from $\mathrm{x}_{16}$ to $\left.\mathrm{x}_{20}\right): \mathrm{x}_{16}-\mathrm{ND} /$ per capita, $\mathrm{x}_{17}$-the percentage of the non-agricultural population, $\mathrm{x}_{18}$-the percentage of an increase/decrease in the number of inhabitants in 2015 in comparison with $2002, \mathrm{x}_{19}$-the share of agriculture in the ND of the economy and $x_{20}$-the share of industry in the ND of the economy.

On the basis of the data as per municipalities, a fact has been established that there is a significant difference between the mean value and the median calculated for the data at the district level because the analyzed features as per municipalities do not represent the normal distribution of data at the district level. The ranking of the districts according to the analyzed features has been done on the basis of the values of the median as per municipalities.

For each one of the mentioned groups of features (production, capacities, the achieved level of development), the I-distance (Ivanović, B. 1972, 1973, 1977, Ivanović, B., Fanchette, S., 1973, Docampo, D., 2011, Jeremić, 2012, Docampo, D., 2011, Hauner, D., Kyobe, A., 2010, Nita, V. 2011), (Formula 1) was applied to rank the districts from 1 to 25 (Rank 1-the best, Rank 25-the worst).

$D_{k}=\sum_{i=1}^{n} \frac{\left|X_{1 k}-X_{1}^{-}\right|}{S_{1}} \prod_{j=1}^{i=1}\left(1-r_{i j}\right)$

By applying a cluster analysis, the homogeneous groups of the districts in Serbia were defined from the standpoint of the volume of the production of beef, pigmeat, sheep meat and poultry meat. The similarities of the districts according to the analyzed features of meat production were defined by the Euclidean measure of distance, and the complete-link method was applied to perform the grouping of the Serbian districts. 
The obtained results of the hierarchical classification are represented by a dendrogram.

For the analysis of the features of production and the capacities $\left(\mathrm{x}_{1}-\mathrm{x}_{15}\right)$, the data of the publication entitled Municipalities in the Republic of Serbia in 2015 by the Republic Statistical Office were used. No data as per districts for the features of the achieved development level $\left(\mathrm{x}_{16}-\mathrm{x}_{20}\right)$ have been published since 2006, so for those features, the publication entitled Municipalities in the Republic of Serbia in 2005 was used (Stevanović at al, 2011, 2012, 2016.).

\section{Results and Discussion}

\section{Marketability of Meat Production}

The volume of the production of livestock products is primarily influenced by the number and productivity of cattle. They are tightly interconnected, although their significance changes during economic development. Having in view the fact that in the postwar stages of the development of the Serbian economy the productivity of the head was low, the number of cattle had a key influence on the development of the production of livestock products. In later economic development, by the selection and regime of the feeding of the head of cattle, productivity became the decisive factor for the production of livestock products.

Figure 1. Indices of the number of cattle and the production of beef, pigmeat, sheep meat and poultry meat in Serbia in 2001-2016

(Cattle)

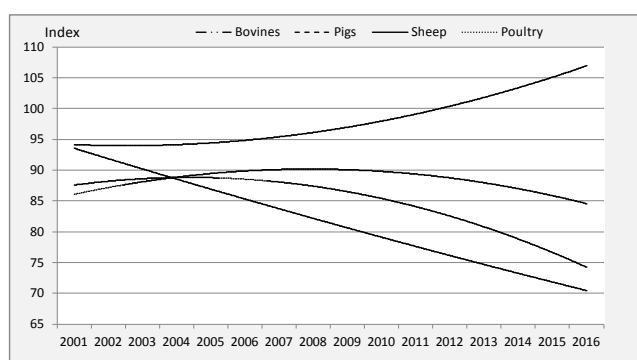

(Meat)

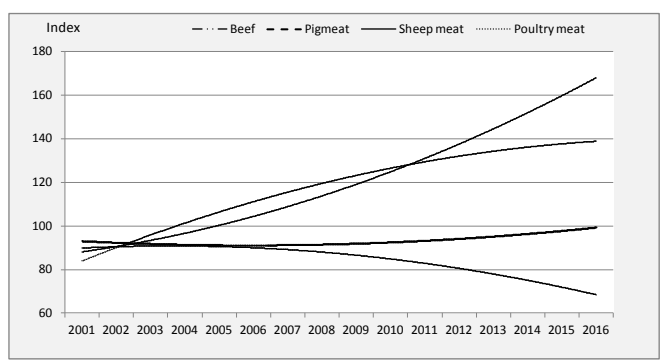

Source: Processed by the Author on the basis of the data of the Republic Statistical Office, Belgrade

In the period from 2001 to 2016 (Figure 1), the number of sheep increased by $11.8 \%$, from 1.49 to 1.67 mill. head (the growth rate of $0.74 \%$ ), whereas the number of bovines, pigs and poultry significantly decreased. The number of bovines was reduced by $23.1 \%$, from 1.2 to 0.9 mill. head (the growth rate of $-1.74 \%$ ), pigs by $16.4 \%$, from 3.6 to 3.0 mill. head (the growth rate of $-1.18 \%$ ) and poultry by $15.8 \%$, from 19.3 to 16.2 mill. head (the growth rate of $-1.14 \%$ ).

A big fluctuation in the number of the livestock population, which is applicable to 
Serbia, causes deep negative consequences in a longer time period (Mijić, at al, 2014). Therefore, it is needed to mitigate not only the variation degree, but also the consequences that arise in animal husbandry, or agricultural production.

Given the significance of bovine breeding, the reduction in the number of the bovine head in Serbia by almost one-fourth will negatively reflect on the overall animal husbandry. The negative tendency in bovine breeding is all the more complex if we bear in mind the length of the reproduction cycle and the structure of the herd.

Insufficient food production, market instability, a reduction in the export of livestock products, cattle and concentrated animal feeding stuffs price disparities and the process of the differentiation of the rural population and the presence of agricultural workforce had the biggest influence on the reduction in the number of bovines. The stated factors have a negative influence on the degree of the utilization of the production potentials of the livestock population, which are reflected in a lower volume of production, productivity and income as per employee. A greater utilization of the production potential would contribute to an increase in animal husbandry, and simultaneously to productivity and revenues in cattle breeding. These tendencies ${ }^{5}$ are especially pronounced in the highland regions of Serbia, where cattle breeding is actually present to the greatest extent.

Not diminishing the significance of bovine breeding and pig breeding, sheep breeding in the Republic of Serbia has a special significance given the highland area, the favorable climatic conditions and available areas under meadows. For some regions (Nišava District and Pirot District), sheep breeding represents a significant, whereas sometimes the only one, source of income for farms and the population. Although it has favorable conditions for the development of sheep breeding, Serbia is deficient in some products (Wool, lamb, milk, milk products) of sheep breeding. In the world market, there has been ever-increasing demand for sheep-breeding products, which represents a chance that Serbia can use in the exporting orientation of agriculture (Ranđelović, Pavlović, 2000).

The production of meat ${ }^{6}$ is contingent upon the number, structure and breed composition of cattle, a yield in liveweight, the volume of slaughter and foreign-trade exchange (Đorović, Tomin, 2010). In the 2001-2016 period (Table 1), the total ${ }^{7}$ average annual production of meat was 453.0 thous. tons, with the annual oscillation of \pm 22.5 thous. tons and the growth rate of $1.09 \%$ per annum. Observed as per meats, the production of beef recorded a negative growth tendency, whereas the production of pigmeat, sheep meat and poultry meat had a positive growth tendency. The average annual production

5 It is reflected in the low average weight of the head, its insufficient fatness, a loss in weight during the winter due to bad nutrition, the premature separation of young head from the herd or the fattening head, the bad structure of the herd, bad stable conditions for keeping the head and so on.

6 The production of meat, in total and as per kinds, represents the so-called meat production in the country, i.e. the meat of slaughtered cattle at the butchers' households and agricultural farms.

7 Beef, pigmeat, sheep meat and poultry meat.

http://ea.bg.ac.rs 
of beef was $87.6 \pm 9.87^{8}$ thous. tons (70-100 thous. t. $)^{9}$, with the negative average annual growth rate of $-1.25 \%$, pigmeat $263.9 \pm 15.98$ thous. tons (242-301 thous. t.), with the growth rate of $1.16 \%$, sheep meat $22.9 \pm 5.20$ thous. tons $(242-301$ thous. t.), with the growth rate of even $4.73 \%$ annually and poultry meat $453.2 \pm 22.55$ thous. tons (420500 thous. t.) and the growth rate of $1.09 \%$.

The data about the standard deviations of the analyzed production of different meats are indicative of the existence of a big annual oscillation in their production, which is negatively reflected on the stability of the offer in the national market, as well as export.

According to the data about the simple correlation coefficients ${ }^{10}$ of the number of cattle and meat production, a conclusion can be drawn that the production of beef and sheep meat is significantly influenced by the number of cattle, whereas it is not the case with the production of pigmeat and poultry meat. The stated is indicative of the fact that the other factors, such as productivity as per head and similar factors, have greater significance for the production of pigmeat and poultry meat. According to (Vlahović, et al. 2006), the production of sheep meat depends on the number and structure of the slaughtered head, the average weight of the slaughtered head, the fatness condition ${ }^{11}$, the genetic characteristics of the breeds which are raised as well as the quality characteristics of meat.

The tendencies in production also had an influence on the change in the structure of meat as per kinds. Due to the negative tendencies in production, the share of beef was reduced from $21.9 \%$ (in 2001) to $15.4 \%$ (in 2016). The share of pigmeat remained unchanged, about $60.0 \%$, whereas the share of sheep meat increased from $4.0 \%$ to $6.8 \%$ and poultry meat from $14.6 \%$ to $17.6 \%$.

The stated data are indicative of the fact that, in the 2001-2016 period, the quantitativequalitative structure of meat production in Serbia underwent change. The total production of meat increased quantitatively by around $17.6 \%$. Observed as per meats, the production of beef decreased, whereas the production of pigmeat, sheep meat and poultry meat increased. Qualitatively ${ }^{12}$, the tendencies in the volume of production as per meats were negative in the production of beef, pigmeat and poultry meat, whereas they were positive only in the production of sheep meat. Serbia has not yet achieved the level of development that will have an influence on change in the qualitative structure of meat production through increased consumption and demand (Milanović, Đorović, 2011).

Table 1. The structure of the production of beef, pigmeat, sheep meat and poultry meat in

8 The standard deviation.

9 Minimum and maximum production in the 2001-2016 period.

10 Bovines r-0.734975, pigs r-0.083248, sheep r-0.626408, poultry r-0.056325.

11 Fattened head have a substantially greater slaughter yield than meager head.

12 The growth of the living standard of a population leads to the following qualitative changes in the structure of meat consumption: there is an increase in the share of beef and sheep meat and a decrease in the share of pigmeat and poultry meat. 
Serbia in 2001-2016

\begin{tabular}{|c|c|c|c|c|c|c|}
\hline \multirow{2}{*}{ Years } & \multirow{2}{*}{$\begin{array}{c}\text { Total } \\
(000 \mathrm{t})\end{array}$} & \multirow{2}{*}{$\begin{array}{c}\text { Index } \\
(2001=100)\end{array}$} & Beef & Pigmeat & $\begin{array}{c}\text { Sheep } \\
\text { meat }\end{array}$ & $\begin{array}{c}\text { Poultry } \\
\text { meat }\end{array}$ \\
\cline { 5 - 7 } & & & & & 4,0 & 14,6 \\
\hline 2001 & 425 & 100,0 & 21,9 & 59,5 & 4,0 & 14,3 \\
\hline 2002 & 454 & 106,8 & 21,4 & 61,0 & 3,3 & 13,8 \\
\hline 2003 & 429 & 100,9 & 22,1 & 60,1 & 4,0 & 15,5 \\
\hline 2004 & 420 & 98,8 & 22,1 & 57,6 & 4,8 & 15,5 \\
\hline 2005 & 431 & 101,4 & 20,9 & 58,7 & 4,9 & 17,3 \\
\hline 2006 & 433 & 101,9 & 19,2 & 58,9 & 4,6 & 14,8 \\
\hline 2007 & 474 & 111,5 & 20,0 & 61,0 & 4,2 & 16,4 \\
\hline 2008 & 464 & 109,2 & 21,3 & 57,3 & 5,0 & 17,5 \\
\hline 2009 & 456 & 107,3 & 21,9 & 55,3 & 5,3 & 17,8 \\
\hline 2010 & 472 & 111,1 & 20,3 & 57,0 & 4,9 & 21,5 \\
\hline 2011 & 479 & 112,7 & 16,9 & 56,6 & 5,0 & 20,9 \\
\hline 2012 & 450 & 105,9 & 18,2 & 56,0 & 4,9 & 20,9 \\
\hline 2013 & 441 & 103,8 & 15,9 & 56,5 & 6,8 & 20,8 \\
\hline 2014 & 452 & 106,4 & 16,2 & 57,1 & 6,0 & 20,8 \\
\hline 2015 & 471 & 110,8 & 16,3 & 59,0 & 6,4 & 18,3 \\
\hline 2016 & 500 & 117,6 & 15,4 & 60,2 & 6,8 & 17,6 \\
\hline
\end{tabular}

Source: Processed by the Author on the basis of the data of the Republic Statistical Office, Belgrade

The share of market production represents an important qualitative characteristic of every production. Market animal husbandry is guided by market economic requirements and needs. Profitable business doing according to the market criteria for production is based on contemporary technical-economic procedures and high productivity. Contrary to that, subsistence economy has a goal of meeting producers' needs and most frequently it is extensive and low-productive (Đorović, et al, 2009).

The relationship between the market and the subsistence parts of animal husbandry is also synthetically expressed by the overall relationship between the production factors and the social-economic conditions in which animal husbandry takes place. It reveals the possibilities and directions of the further development of animal husbandry. In that sense, studying the marketability of animal husbandry encompasses the measuring of the relationship between the market and the subsistence economy and finding out the tendencies in the production structure. 
Table 2. The production of meat and the marketability degree as per regions and districts in Serbia in 2015

\begin{tabular}{|c|c|c|c|c|c|c|c|c|}
\hline & \multicolumn{4}{|c|}{ Production $(\mathrm{t})$} & \multicolumn{4}{|c|}{ Marketability degree $(\%)$} \\
\hline & Beef & Pigmeat & $\begin{array}{l}\text { Sheep } \\
\text { meat }\end{array}$ & $\begin{array}{c}\text { Poultry } \\
\text { meat }\end{array}$ & Beef & Pigmeat & $\begin{array}{r}\text { Sheep } \\
\text { meat }\end{array}$ & $\begin{array}{c}\text { Poultry } \\
\text { meat }\end{array}$ \\
\hline $\begin{array}{l}\text { REPUBLIC OF SERBIA } \\
(000 \mathrm{t})\end{array}$ & 85.6 & 263.9 & 24.3 & 85.4 & 16.4 & 15.6 & 27.0 & 16.9 \\
\hline SERBIA - NORTH $(000 \mathrm{t})$ & 28.8 & 124.0 & 4.9 & 42.1 & -25.0 & 9.6 & -81.9 & 15.3 \\
\hline Belgrade District & 79.7 & 591.3 & 16.5 & 147.7 & -378.7 & -221.3 & -938.1 & -538.3 \\
\hline Vojvodina Region $(000 \mathrm{t})$ & 23.8 & 108.3 & 3.8 & 38.3 & 19.9 & 45.2 & -24.3 & 50.6 \\
\hline Western Bačka District & 644.2 & 1586.7 & 67.2 & 488.4 & 24.6 & 31.6 & -68.0 & 19.0 \\
\hline Southern Banat District & 301.4 & 1165.6 & 78.2 & 556.3 & 29.6 & 30.2 & 18.8 & 22.1 \\
\hline Southern Bačka District & 282.6 & 1623.5 & 55.6 & 751.9 & 8.8 & 51.7 & -19.0 & 41.6 \\
\hline Northern Banat District & 533.4 & 1632.6 & 106.2 & 122.8 & 66.4 & 64.4 & 54.4 & -23.3 \\
\hline Norhtern Bačka District & 1109.2 & 6010.7 & 89.6 & 1235.2 & 46.2 & 29.4 & -20.0 & 79.3 \\
\hline Middle Banat District & 614.4 & 1090.9 & 112.4 & 861.1 & 62.1 & 51.0 & 46.0 & 73.2 \\
\hline Srem District & 422.7 & 3360.1 & 59.7 & 570.2 & 20.1 & 66.9 & 4.5 & -9.1 \\
\hline SERBIA - SOUTH $(000 \mathrm{t})$ & 56.8 & 139.9 & 19.4 & 43.3 & 37.5 & 20.9 & 54.6 & 18.5 \\
\hline $\begin{array}{l}\text { Šumadija and Western } \\
\text { Serbia Region }(000 t)\end{array}$ & 39.0 & 89.2 & 14.7 & 29.7 & 49.0 & 30.6 & 66.4 & 33.5 \\
\hline Zlatibor District & 625.7 & 416.5 & 340.0 & 124.4 & 51.8 & -48.1 & 81.0 & -42.1 \\
\hline Kolubara District & 779.6 & 1539.7 & 301.2 & 616.9 & 74.5 & 66.9 & 83.0 & 62.9 \\
\hline Mačva District & 736.0 & 2504.5 & 258.0 & 386.6 & 60.6 & 64.7 & 77.4 & 18.1 \\
\hline Moravica District & 881.0 & 1215.9 & 379.8 & 213.3 & 57.5 & -2.5 & 79.6 & -61.0 \\
\hline Morava River Basin District & 428.6 & 1214.5 & 146.0 & 718.1 & 21.6 & 30.6 & 30.8 & 63.0 \\
\hline Rasina District & 400.1 & 1451.0 & 186.7 & 1199.1 & 25.7 & 29.5 & 32.5 & 58.6 \\
\hline Raška District & 909.2 & 389.9 & 225.2 & 162.3 & 14.2 & -89.9 & 45.4 & -45.3 \\
\hline Šumadija District & 410.5 & 1383.7 & 290.9 & 369.5 & 14.4 & 37.8 & 71.6 & 32.4 \\
\hline $\begin{array}{l}\text { Southern and Eastern Serbia } \\
\text { Region }(000 \mathrm{t})\end{array}$ & 17.8 & 50.7 & 4.7 & 13.6 & 32.1 & 3.9 & 18.1 & -14.0 \\
\hline Bor District & 366.9 & 674.1 & 117.3 & 135.2 & 20.1 & -40.1 & 34.2 & -97.0 \\
\hline Braničevo District & 267.7 & 1201.1 & 139.0 & 262.7 & 48.3 & 68.4 & 70.3 & 48.3 \\
\hline Zaječar District & 485.8 & 814.3 & 171.6 & 171.3 & 44.3 & 42.2 & 65.6 & -43.0 \\
\hline Jablanica District & 235.4 & 546.6 & 39.0 & 170.4 & 53.8 & -25.4 & -51.5 & -22.2 \\
\hline Nišava District & 270.5 & 726.6 & 73.6 & 224.0 & 37.7 & 27.5 & 22.5 & 7.6 \\
\hline Pirot District & 190.8 & 284.8 & 118.4 & 148.1 & 25.6 & -104.9 & 67.1 & -53.5 \\
\hline Danube River Basin District & 497.4 & 3029.3 & 183.0 & 883.3 & 20.5 & 50.3 & 46.4 & 3.3 \\
\hline Pčinj District & 272.7 & 348.2 & 44.6 & 162.7 & 19.0 & -74.6 & -67.1 & -53.6 \\
\hline Toplica District & 363.2 & 611.0 & 83.6 & 147.8 & 27.3 & -13.0 & 10.9 & -16.1 \\
\hline
\end{tabular}

Source: Processed by the Author on the basis of the data of the Republic Statistical Office, Belgrade

In Serbia, according to the data for 2015 (Table 2), the degree of the marketability ${ }^{13}$ of beef was $16.4 \%$, pigmeat $15.6 \%$, sheep meat $27.0 \%$ and poultry meat $16.9 \%$. The Serbia-North Region recorded a deficit in the market production of beef of $-25.0 \%$ and of sheep meat $-81.9 \%$, whereas there was a surplus of the market production of pigmeat of $9.6 \%$ and poultry meat of $15.3 \%$. In the Serbia-South Region, a market surplus of all meats was recorded (beef $37.5 \%$, pigmeat $20.9 \%$, sheep meat $54.6 \%$ and poultry meat $18.5 \%)$.

In Belgrade District, a deficit of all meats was recorded, namely beef $-378.7 \%$, pigmeat $-221.3 \%$, sheep meat $-938.1 \%$ and poultry meat $538.3 \%$. In the districts of Vojvodina

13 (production surplus)/total production)*100 
Region, there is a deficit of sheep meat in the three Bačka districts (Western Bačka $-68.0 \%$, Southern Bačka $-19.0 \%$ and Northern Bačka $-20.0 \%$ ) of on average $24.3 \%$ and poultry meat in the two districts (Middle Banat $-23.3 \%$ and Srem $-9.1 \%$ ). The other districts of Vojvodina Region have a surplus of beef, pigmeat, sheep meat and poultry meat from $8.8 \%$ to $79.3 \%$.

The high level of the marketability of the production of beef in AP of Vojvodina is a result of the low consumption of beef in the nutrition of the population. Traditionally, the population of the AP of Vojvodina predominantly consumes pigmeat and poultry meat in its nutrition. Because of that, the production of poultry meat is traditionally subsistent. Favorable conditions for breeding pigs have as a consequence the volume of production that, even apart from the pronounced presence of pigmeat in the population's nutrition, enables the production of pigmeat to have a high marketability level (Lakić, Stevanović, 2003).

The average marketability of the production of meat in the Region of Šmadija and Western Serbia ranges from $30.6 \%$ for pigmeat to $66.4 \%$ for sheep meat. Yet, the three districts of the Region of Šumadija and Western Serbia (Zlatibor, Moravica and Raška) have a deficit of the market production of pigmeat and poultry meat, whereas the other fields have a surplus of the market production of all meats.

In the Region of Southern and Eastern Serbia, there is a deficit of poultry meat of $-14.0 \%$, whereas the other meats record a surplus of market production from $3.9 \%$ for pigmeat to $32.1 \%$ for beef. Also, in all the districts of this region, there is a surplus of beef. The two districts of this region (Jablanica and Pčinja Districts) have a deficit of the three meats (pigmeat, sheep meat and poultry meat), and the three districts have a deficit of the two meats (pigmeat and poultry meat).

According to the simple correlation coefficients, the production of pigmeat $(\mathrm{r}=0.854)$ has, to the greatest extent, an influence on the total meat production. It is followed by the production of sheep meat $(\mathrm{r}=0.587)$ and poultry meat $(\mathrm{r}=0.571)$, whereas the smallest influence is that of beef production $(\mathrm{r}=0.179)$.

\section{Cluster Analysis of Meat Production in Serbia}

The ranking of the districts in Serbia according to the production of beef, pigmeat, sheep meat and poultry meat was done by calculating the I-distance values for the three groups of the features (production, the capacities, and the achieved level of development). 
Table 3. The ranks of the districts according to the production of beef, pigmeat, sheep meat and poultry meat in Serbia, according to the I-distance

\begin{tabular}{|c|c|c|c|c|c|c|}
\hline \multirow[t]{2}{*}{ Districts } & \multicolumn{2}{|c|}{ Features of production } & \multicolumn{2}{|c|}{ Features of the capacities } & \multicolumn{2}{|c|}{$\begin{array}{l}\text { Features of the } \\
\text { achieved level of } \\
\text { development }\end{array}$} \\
\hline & I-distance & Rank & I-distance & Rank & I-distance & Rank \\
\hline Northern Bačka & 66.49 & 1 & 2.72 & 22 & 15.43 & 4 \\
\hline Kolubara & 41.70 & 2 & 7.41 & 11 & 21.49 & 7 \\
\hline Mačva & 37.65 & 3 & 20.09 & 5 & 20.17 & 10 \\
\hline Middle Banat & 37.05 & 4 & 38.01 & 1 & 21.74 & 6 \\
\hline Rasina & 35.44 & 5 & 9.39 & 9 & 17.24 & 16 \\
\hline Moravica & 34.26 & 6 & 20.03 & 6 & 21.00 & 9 \\
\hline Danube River Basin & 34.02 & 7 & 2.96 & 21 & 10.65 & 17 \\
\hline Morava River Basin & 32.35 & 8 & 13.27 & 8 & 11.74 & 15 \\
\hline Srem & 31.38 & 9 & 3.05 & 19 & 14.04 & 5 \\
\hline Western Bačka & 31.30 & 10 & 2.07 & 25 & 23.59 & 3 \\
\hline Šumadija & 31.07 & 11 & 13.88 & 7 & 18.44 & 14 \\
\hline Raška & 30.65 & 12 & 21.31 & 4 & 18.29 & 23 \\
\hline Southern Bačka & 30.07 & 13 & 8.80 & 10 & 21.41 & 8 \\
\hline Braničevo & 30.03 & 14 & 22.77 & 3 & 19.44 & 12 \\
\hline Northern Banat & 28.13 & 15 & 6.57 & 12 & 24.37 & 2 \\
\hline Zlatibor & 27.62 & 16 & 24.26 & 2 & 20.02 & 11 \\
\hline Southern Banat & 27.28 & 17 & 6.24 & 13 & 19.29 & 13 \\
\hline Zaječar & 25.23 & 18 & 5.17 & 16 & 11.26 & 24 \\
\hline Nišava & 25.13 & 19 & 5.32 & 15 & 21.98 & 21 \\
\hline Toplica & 23.12 & 20 & 4.47 & 17 & 15.37 & 18 \\
\hline Jablanica & 21.48 & 21 & 2.23 & 24 & 13.06 & 22 \\
\hline Pčinj & 18.52 & 22 & 5.45 & 14 & 15.27 & 19 \\
\hline Pirot & 18.39 & 23 & 3.56 & 18 & 22.96 & 25 \\
\hline Bor & 18.08 & 24 & 2.66 & 23 & 14.15 & 20 \\
\hline Belgrade & 0.05 & 25 & 3.03 & 20 & 33.81 & 1 \\
\hline
\end{tabular}

Source: The calculation done by the Author on the basis of the data obtained from the RSO, Belgrade.

The production of beef, pigmeat, sheep meat and poultry meat is present in all of the 25 Serbian districts. However, the districts significantly differ from one another according to the features of meat production, the capacities and the achieved level of development. So, according to the features of meat production, the districts that belong to the 1-5 Rank, according to the features of the capacities belong to the Ranks from 1 to 22 , and according to the features of the achieved level of development to the Ranks from 4 to 16 (Table 3 ). The stated indicates that the production of beef, pigmeat, sheep meat and poultry meat is not directly related to the features of the capacities and the achieved level of development.

With the exception of Belgrade District, as the most developed in Serbia, the other districts that are ranked the lowest with respect to the feature of meat production are also ranked low with respect to the feature of the capacities (Ranks 14-23) and the achieved level of development (Ranks 18-25). 
Figure 2. The dendrogram of the production of beef, pigmeat, sheep meat and poultry meat as per districts in Serbia

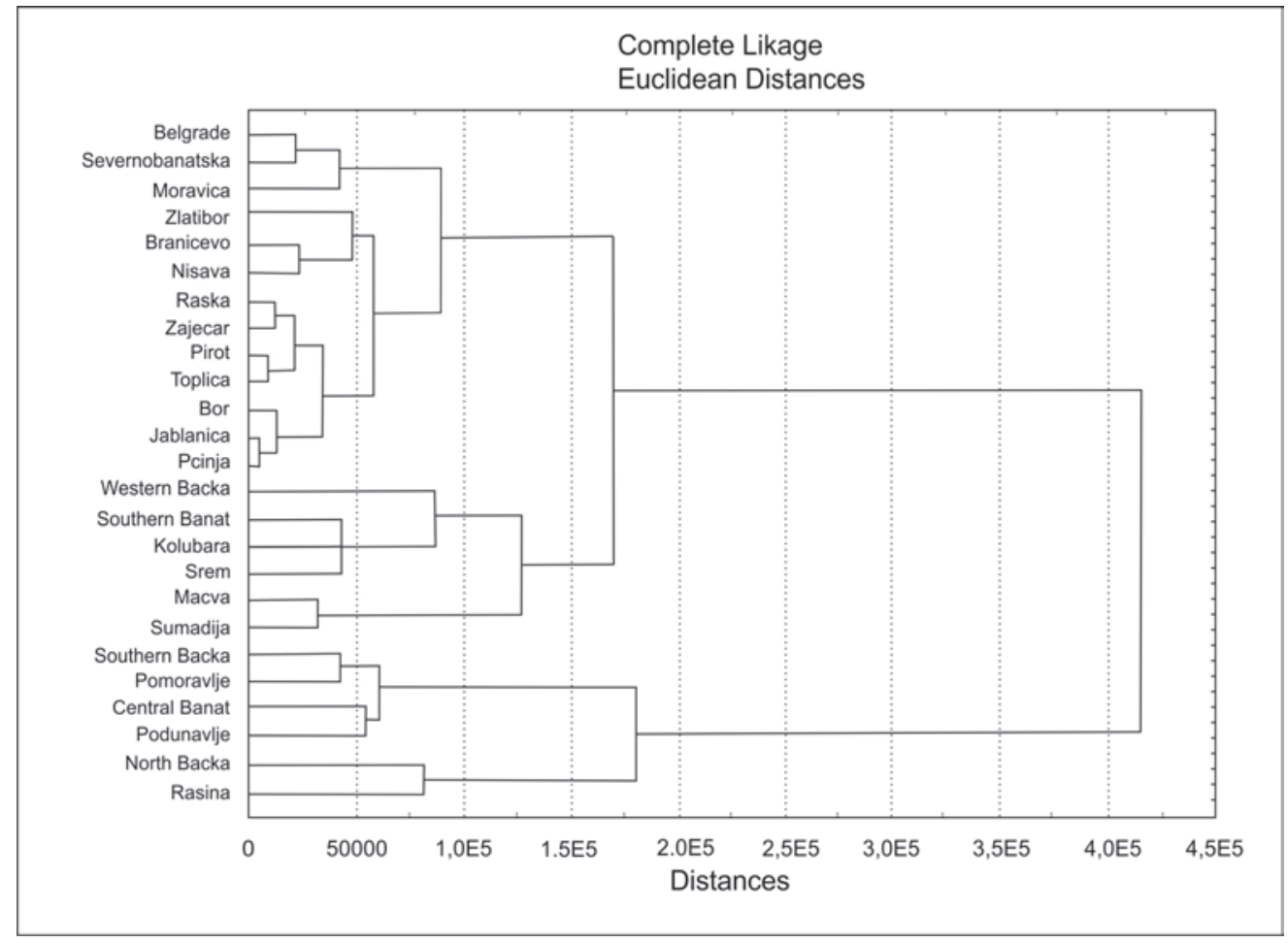

Source: Author's Research.

In the dendrogram (Figure 2), the four clusters of the districts of the production of beef, pigmeat, sheep meat and poultry meat in Serbia are identified. The first cluster is the most numerous and encompasses 13 districts, the second cluster-six districts, the third-four districts and the fourth-two districts.

The first cluster consists of two sub-clusters. The first sub-cluster encompasses three districts: two from within the Serbia-North Region and one from the Serbia-South Region. According to the features of meat production, the districts of this cluster belong to the Ranks 6, 15 and 25; according to the features of the capacities, they belong to the Ranks 6, 12 and 20, whereas according to the features of the achieved level of development, they fall within Serbia's more developed areas (Belgrade District-Rank 1, Northern Banat-Rank 2, and Moravica-Rank 9). The second sub-cluster encompasses the 10 districts of the Serbia-South Region, of which only two belong to Sumadija and Western Serbia Region, 8 to Southern and Eastern Serbia Region. According to the features of production, the districts of Šumadija and Western Serbia Region belong to Ranks 12 (Raška District) and 16 (Zlatibor District), according to the features of the capacities-to Clusters 4 and 2, and according to the features of the achieved level of development-to Ranks 23 and 11. The districts that belong to Southern and Eastern 
Serbia Region belong to Ranks 18-24 according to the features of production, to Ranks 14-23 according to the features of the capacities, and to Ranks 18-25 according to the achieved level of development. Braničevo District is the exception-according to the above-stated three groups of features, this district belongs to Ranks 14, 3, and 12. The fields of this sub-cluster belong to the Serbian highland areas, rich in the capacities for meat production, but of extensive production, which also has a low degree of development as a consequence.

The second cluster consists of six districts: three from Vojvodina Region and three from Šmadija and Western Serbia Region. According to the features of production, Kolubara and Mačva Districts belong to a high rank (2 and 3), according to the capacities-to Ranks 11 and 5, and according to the features of the achieved level of developmentto Ranks 7 and 10. Srem and Western Bačka Districts belong to the most developed areas of this cluster (Ranks 5 and 3), but they rank low according to the features of the capacities (Ranks 19 and 25). The stated indicates that intensive meat production is performed in these districts. According to the features of production, Sumadija and Southern Banat Districts belong to Ranks 11 and 17, according to the features of the capacities-to Ranks 7 and 13, and according to the features of the achieved level of development-to Ranks 14 and 13.

The third cluster encompasses four districts: two from Vojvodina Region (Southern Bačka and Middle Banat Districts) and one district from Šumadija and Western Serbia Region (Morava River Basin District) and one from Southern and Eastern Serbia Region (Danube River Basin District). According to the features of production, the districts of Vojvodina Region belong to Ranks 4 and 13, according to the features of the capacities-to Ranks 1 and 10, and according to the features of the achieved level of development-to Ranks 6 and 8. According to the features of production, the districts of Serbia-South Region belong to Ranks 7 and 8, according to the features of the capacities-to Ranks 21 and 8, and according to the features of the achieved level of development-to Ranks 17 and 15.

The fourth cluster only encompasses two districts: one from Vojvodina Region (Northern Bačka), and one from Šumadija and Western Serbia Region (Rasina District). According to the observed groups of features, Northern Bačka District belongs to Ranks 1, 22 and 4, and Rasina District belongs to Ranks 5, 9 and 16. Northern Bačka District is characterized by the intensive production of beef, pigmeat and poultry meat.

\section{Conclusion}

Through meat production, crop raising inputs are also valorized into animal husbandry as a higher stage of finalization. The value of meat production is a result of the multiplied value of investment in animal husbandry. The growth of the productivity of meat production represents a broader synthetic factor, whose degree of influence is determined by all the factors that are related to the development of cattle breeding and represent the factors of beef production. 
Therefore, cattle breeding may well be expected to have a greater influence on the development of agriculture. Having in view the structure of meat production in Serbia (beef $20 \%$, pigmeat $60 \%$, sheep meat $5 \%$ and poultry meat $15 \%$ ), the production of pigmeat is the only one that can be expected to have an influence on the development of agriculture as a field. The number of pigs in the observed period, however, was significantly reduced, which reflected on the stagnation of pigmeat production.

Qualitatively observed, the tendencies in the volume of meat production as per kinds of meat are negative in the production of beef, pigmeat and poultry meat, whereas they are only positive in the production of sheep meat. The stated indicates that there is still a low level of the living standard of the Serbian population, which negatively reflects on the qualitative changes in the structure of meat production.

By the analysis of meat production as per kinds of meat, the level of achieved economic development and the share of agriculture in the economic structure, no fact was established across the Serbian districts that there is a high interdependence between meat production and the achieved level of economic development. However, when the farms on which meat production represents the dominant or the only one part of the source of income, as well as the districts in which this type of production is present more than the other types, are concerned, meat production has a great influence on the creation of agricultural revenue, i.e. the GDP of the economy as a whole.

The accelerated economic development of a country, an increase in real salaries, the advancement of agricultural production, an increase in demand for livestock products, as well as the export of livestock products, enable the creation of socialeconomic and institutional conditions for a faster and more intensive development of animal husbandry. The application of contemporary technology has increasingly been assuming ever-greater proportions in animal husbandry, which is increasingly turning it into industrialized production. That has an influence on the transformation of cattle breeding into an intensive and the most significant branch of agricultural production.

\section{Acknowledgements}

This paper was performed as part of Project No. 179028 and Project No. 179001 funded by the Ministry of Education, Science and Technological Development, Republic of Serbia.

\section{Conflict of interests}

The authors declare no conflict of interest.

\section{References}

1. Devetaković, S. (2008). Regions and Regional Development in Serbia today, Proceedings Economic Policy and Economic Development, University of Belgrade, Belgrade, p. 75-90. [in Serbian: Regioni i regionalni razvoj u Srbiji danas. Tematski zbornik Ekonomska politika i privredni razvoj. Univerzitet u Beogradu, Ekonomski fakultet, Beograd]. 
2. Docampo, D. (2011). On using the Shanghai ranking to assess the research performance of university systems, Scientometrics, 86(1)77-92.

3. Đorović, M., Stevanović, S., Lazić V. (2009). Global market meat, Economics of Agriculture, 53(3)343-358.

4. Đorović, M., Tomin, A. (2010). Market and trade of agricultural products, University of Belgrade, Faculty of Agriculture, Belgrade, p. 1-446. [in Serbian: Tržište i promet poljoprivrednih proizvoda, Univerzitet u Beogradu, Poljoprivredni fakultet, Beograd, str. 1-446].

5. Hauner, D., Kyobe, A. (2010). Determinants of government efficiency, World Development, 38(11)1527-1542.

6. Ivanović, B. (1972). Classification and selection of statistical characteristics, Statistička revija, No. 1-2. [in Serbian: Klasifikacija i izbor statističkih obeležja, Statistička revija, br. 1-2].

7. Ivanović, B. (1973). A method of establishing a list of development indicators, United Nations educational, Scientific and cultural organization, Paris.

8. Ivanović, B., Fanchette, S. (1973). Grouping and ranking of 30 countries of SubSaharan Africa, Two distance-based methods compared, Paris: United Nations educational, scientific and cultural organization.

9. Ivanović, B. (1977). Classification theory, Institute for Economic Research, Belgrade. [in Serbian: Teorija klasifikacije, Institut za ekonomska istraživanja, Beograd.]

10. Jeremić, V. (2012). Statistical Efficiency Model Based on the Ivanovic Distance, University of Belgrade, Faculty of organizational sciences, Belgrade, (Doctoral Dissertation) [in Serbian: Statistički model efikasnosti zasnovan na Ivanovićevom odstojanju, Univerzitet u Beogradu, Fakultet organizacionih nauka, Beograd, (Doktorska disertacija).] http://www.doiserbia.nb.rs/phd/university. aspx?theseid=BG20121001JEREMIC\#.WTFWGtwlFhF

11. Lakić N, Stevanović S. (2003). Ranking of the Municipalities of AP Vojvodina According to Multidimensional Denominator of the Goods of Cattle Breeding Production, Journal of Agricultural Sciences, 48(2)217-226.

12. Mijić, K. Zekić, S., Jakšić, D., Vuković, B. (2014). Meat industry in Serbia: performance analysis of meat-processing and livestock companies (Article), CUSTOS E AGRONEGOCIO ON LINE, 10(3)124-144.

13. Milanović, M., Đorović, M. (2011). Agricultural products market in Serbia before and after the transition, Institute of Agricultural Economics, Belgrade, p. 1-230. [Tržište poljoprivrednih proizvoda u Srbiji pre i posle tranzicije, Institut za ekonomiku poljoprivrede, Beograd].

14. Nita, V. (2011). An extended approach to e-inclusion and its implications for Romania, Romanian Journal of European Affairs, 11(1)63-80.

15. Official Gazette of the Republic of Serbia, The Report No 109/09 and 46/10.

16. Ranđelović, V., Pavlović, M. (2000). Sheep, factor of development of animal 
husbandry and villages, Cooperative Union of Serbia, Belgrade, p. 1-14. [in Serbian: Ovčarstvo, faktor razvoja stočarstva i sela, Zadružni savez Srbije, Beograd].

17. Statistical Yearbook of Serbia: Municipalities in Serbia, Statistical Office of the Republic of Serbia, Belgrade. [in Serbian: Statistički godišnjak Srbije: Opštine u Srbiji, RZS, Beograd].

18. Stevanović, S. (2002). Encouraging market production in agriculture - the concept of sustainable development of rural areas, Ekonomski anali, (46)284292. [in Serbian: Podsticanje tržišne proizvodnje u poljoprivredi-koncept održivog razvoja ruralnih područja, Ekonomski anali, (46)284-292].

19. Stevanović, S. (2005). The economic aspect of development of consumption of fish in the world, Proceedings „Fishing“, Faculty of Agriculture Belgrade nad Akvaforsk Institute of Aquaculture Research AS, Norway, Belgrade, p 196206. [in Serbian: Ekonomski aspekt razvoja potrošnje ribe u svetu, Zbornik radova-Druga međunarodna konferencija „Ribarstvo“, Poljoprivredni fakultet i Akvaforsk Institute of Aquaculture Research AS, Norway, Beograd].

20. Stevanović, S. (2009). The development market production in the agriculture of the Republic of Serbia, MonoFigurey, Association of Agricultural Economists in Serbia and Faculty of agriculture, Belgrade, p. 1-222. [in Serbian: Razvoj tržišne proizvodnje u poljoprivredi Republike Srbije, monografija, Društvo agrarnih ekonomista Srbije i Univerziteta u Beogradu, Poljoprivredni fakultet, Beograd]

21. Stevanović, S., Đorović, M. (2011). Development of the market orieneted production of agricultural products as a factor in the reduction of rural poverty in the Republic of Serbia, Economics of Agriculture, 58(Special Issue-2)17-38. [in Serbian: Razvoj tržišne proizvodnje ratarskih proizvoda kao činilac smanjenja ruralnog siromaštva u Republici Srbiji, Eknomika poljoprivrede, 58(SB-2)17-38]. http://bsaae.bg.ac.rs/images/Ekonomika\%20kompletna/2011/ Specijalni\%20broj\%202.pdf

22. Stevanović, S., Đorović, M., Milanović, M. (2012). The development of the market production of cereals in Serbia: example wheat and corn, Economics of Agriculture, 59(4)617-632.

23. Stevanović, S., Milanović, M. (2016). Regional Characteristics of Market Production of Sugar Beet and Sunflower in Serbia, Marketing, 47(2)137-147. http://www.sema.rs/repository/download/marketing-vol-47-no-2.pdf

24. Tomić, D., Simonović, V. (2008). The interdependence of crop and livestock production, Proceedings, Agriculture and Rural Affairs - ideas and initiatives, Association of Agricultural Economists of Serbia, Belgrade, p 131-137. [in Serbian: Međuzavisnost ratarske i stočarske proizvodnje, Zbornik Poljoprivreda i selo-ideje i inicijative, Društvo agrarnih ekonomista Srbije, Beograd].

25. Vlahović, B., Stevanović, S., Tomašević, D., Zelenjak, M. (2006). Agricultural production in the Republic of Serbia, Association of Agricultural Economists of Serbia, Belgrade, p. 209-242. [in Serbian: Agrarna proizvodnja u Republici Srbiji, Društvo agrarnih ekonomista Srbije, Beograd]. 